\title{
The problem with gender
}

\author{
DAVID CREWS \\ University of Texas at Austin, Austin, Texas
}

\begin{abstract}
Webster's defines gender as the classification of animate beings and inanimate things as masculine, feminine, or neuter. When used as a concept that guides how we perceive and study sexuality, gender becomes nebulous: To some, gender is defined in terms of behavior, whereas others regard gender as indicative of chromosome constitution. However, gender is an anthropocentric psychological construct that has little meaning when dealing with nonhuman organisms. In such investigations clarity and precision of definitions of sexuality are paramount. This essay demonstrates that sexuality is not a unitary phenomenon, but rather a multifaceted composite of different sexes that may or may not be concordant. The essay further suggests that the components of sexuality be considered in terms of complementary mechanisms and outcomes.
\end{abstract}

The essential complementarity of sexual reproduction is expressed as dimorphisms, or consistent differences between males and females in reproductive tissues and their functional products. These differences are often referred to as gender differences. As a concept in scientific research, however, gender can be problematical. Because of the very nature of sexual reproduction, requiring as it does two sexes, gender has become a term used in different ways to describe and account for many phenomena occurring at many levels of biological organization. For example, some define gender in terms of behavior, whereas others regard gender as indicative of chromosomal constitution. This vagary creates problems when trying to determine the bases of sex differences. The magnitude of this problem is not immediately apparent because, with the exception of pathology, these two elements are fundamentally and functionally linked in the eutherian mammals and birds that are most often studied. Recent research indicates that, when we look to the reptiles, the ancestors of mammals and birds, some of our assumptions about how sex chromosomes and sexual behaviors are related are violated. The fact that in mammals and birds males and females differ in both behavior and chromosomes may seem to be an intractable confounding variable in all sex differences research. This need not be true. This essay discusses two animal model systems in which behavior or chromosomes cannot be used to define gender. In so doing, they give us a new perspective of the generality of some of our most fundamental assumptions regarding gender-related traits.

\footnotetext{
This paper is dedicated to the memory of Frank A. Beach. The research reported here was supported in part by Grant MH41770 and by National Institutes of Mental Health Research Scientist Award 00135 to the author. I wish to thank J. J. Bull, Martha McClintock, and Jane Stewart for reading the manuscript. I have also benefited from J. J. Bull's drawing my attention to the elegance of Coyne's Rule, a recent clarification of Haldane's Rule. Address correspondence to David Crews, Institute of Reproductive Biology, Department of Zoology, University of Texas at Austin, Patterson Laboratories Building, Austin, TX 78712.
}

\section{Gender Regarded as Behavior}

Consider the commonly used categories of "male sexual behavior" and "female sexual behavior." There is a basic problem with investigating the basis of these gender-related behaviors, because (1) there are two sexes and (2) there is a tendency to define and describe each sex in relation to the other. Two sexes, then, becomes a confounding variable in any experimental investigation of gender-related behaviors. But is this inevitable? Such a question becomes important because if it were possible to "control" for the fact of two sexes, then it would be possible to examine the extent to which sexual behaviors are mutually exclusive or complementary.

\section{Gender Regarded as Chromosomes}

In all mammals, the chromosomal constitution of gonadal males is different from that of gonadal females. But are sex chromosomes equivalent to, or even responsible for, gender-related differences? Our concepts regarding sexual differentiation have been based on organisms that exhibit genotypic sex-determining mechanisms. Were it possible to obtain organisms that lack sex chromosomes but that still exhibit sexual reproduction with its associated behaviors, we could begin to examine the genetic basis of sexuality from a new perspective.

Elsewhere, I have discussed the manifold meanings of sex and the degree to which genetic sex, gonadal sex, anatomical sex, hormonal sex, and behavioral sex are associated (Crews, 1987b). Here, I discuss two commonly held perspectives of gender and how research with atypical animals allows one to circumvent the difficulties inherent in each. I show how study of a parthenogenetic whiptail lizard species that lacks males reinforces the conclusions that (1) the categories of male sexual behavior and female sexual behavior leave an inaccurate picture of sexuality; (2) the vertebrate brain contains dual neural circuits, one that subserves mounting behavior and the other receptive behavior; and (3) the complementarity of specific behaviors is fundamental to successful reproduction. Study of the leopard gecko, a gonochoristic species 
lacking a genotypic sex-determining mechanism, indicates that the genetic information relating to sexual behaviors need not be associated with sex chromosomes.

\section{GENDER AS BEHAVIOR}

Numerous studies indicate that most sexual behaviors differ between the sexes mainly in frequency. In gonochoristic species (separate sexes in separate individuals), gonadal males are more likely to mount, whereas gonadal females are more likely to be mounted (hereafter called homotypical sexual behaviors). However, it is important to keep in mind that individuals can and normally do exhibit behaviors typical of the opposite sex (hereafter called heterotypical sexual behaviors). The display of heterotypical behaviors is common in many animals, particularly mammals (Beach, 1968; Dagg, 1984). For example, female-female mounting in cattle advertises estrus, whereas female-female mounting in the rhesus monkey is important in maintaining social harmony. Thus, male sexual behavior and female sexual behavior more accurately refer to the probability that individuals possessing testes or ovaries will exhibit certain suites of displays and actions rather than a strict gonadspecificity of these behaviors. In those few instances that may be regarded as gonad-specific, such as the behaviors observed during ejaculation and nursing, the absence or abbreviated nature of the behavior in the opposite gonadal sex may be due to the diminished development or absence of the structures involved in the execution of the behavioral display (Kelley, 1988).

The fact that individuals of each gonadal sex have the ability to behave as the opposite sex implies that neural substrates for both behaviors exist in each individual. How can we control for the presence of two sexes in sex differences research? Unisexual animals offer an unusual opportunity to study this problem since they are anatomically and hormonally female-like, yet retain behavioral bisexuality (Crews, in press).

\section{The Whiptail Lizards}

The Cnemidophorus lizards of southern North America and Central and South America are a large and diverse genus. Of the 45 species that constitute the genus, twothirds are gonochoristic, having both male and female individuals that reproduce sexually. However, fully onethird of the species are unisexual, consisting only of individuals that reproduce by true parthenogenesis. Most, if not all, of the parthenogenetic whiptail species are believed to have a hybrid origin, and in many instances, the genealogy of the parthenogen is known. On the basis of cytogenetic evidence, Lowe and Wright (1966) proposed that $C$. gularis is the paternal ancestor to the parthenogenetic whiptail, $C$. uniparens (Figure 1). More recently, restriction endonuclease analyses of mitochondrial DNA have established that $C$. inornatus is the maternal ancestor of $C$. uniparens (Densmore, Moritz, Wright, \& Brown, in press). There is good reason to believe that
Evolution of the Triploid Cnemidophorus uniparens

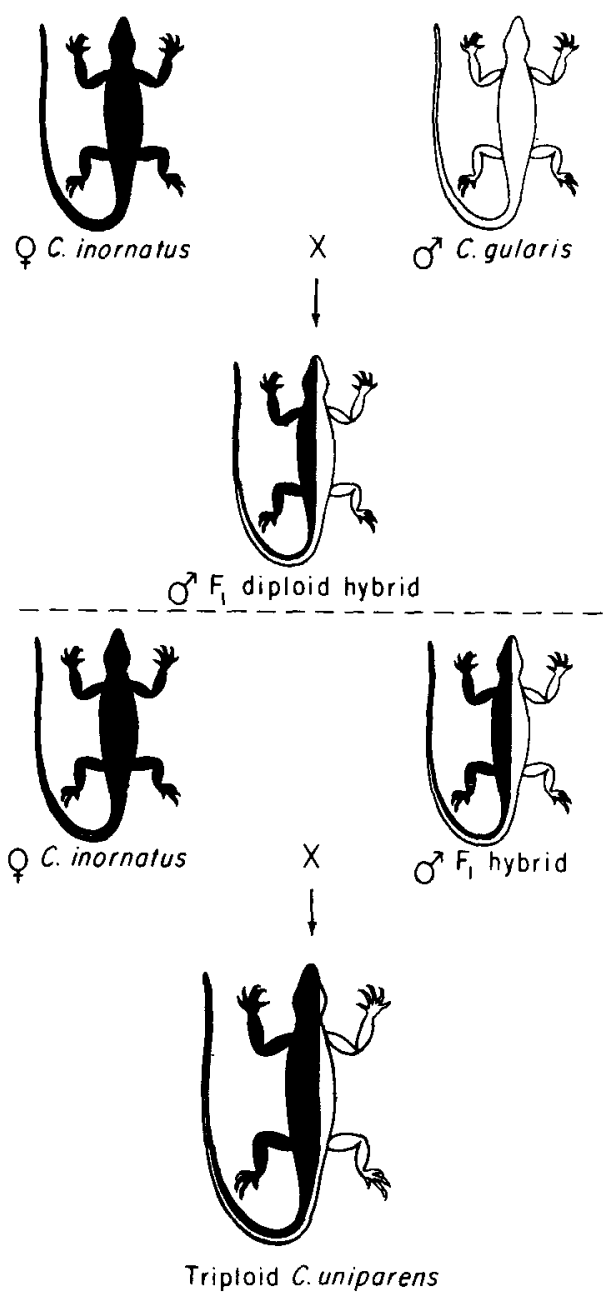

Figure 1. Lineage of the all-female whiptail lizard, Cnemidophorus uniparens. See text for further details.

the maternal ancestral species has a certain trait-a polymorphism in the behavioral sensitivity to progesteronethat may help explain why $C$. inornatus has been involved in the production of at least nine parthenogenetic species. Attempts to recreate the original hybridization event have not been successful.

Only one cnemidophorine species (C. tigris) has been found to have heteromorphic sex chromosomes. As in mammals, the male is the heterogamete, but the degree of the chromosomal heteromorphism is reduced and considered to be at a primitive state of chromosomal evolution (Bull, 1978; Cole, Lowe, \& Wright, 1969). Although heteromorphic sex chromosomes are not evident in other sexual species, it is assumed that gonadal sex is determined by genetic mechanisms. Evidence for this hypothesis is that despite the lack of obvious sex chromosomes, which also applies to species exhibiting environmental sex determination (see below), the normal sex ratio of both the sexual and unisexual species are not altered when eggs 
are incubated under different temperatures (Crews \& Bull, 1988). Finally, many, but not all, parthenogens are polyploid (Dawley, in press).

\section{Sexual Versus Pseudosexual Behavior}

The fundamental difference between sexual and unisexual organisms makes it important to have subtle but necessary semantic rules. For example, although parthenogenetic whiptails have ovaries and lack male genitalia, it is not appropriate to refer to them as females; "female" has meaning only in the context of "male." However, parthenogenetic whiptails exhibit behaviors seen commonly in sexually active male whiptails during mating. Since male-typical and female-typical sexual behaviors can refer only to those behavioral displays associated with males and females in gonochoristic species (e.g., intromission and receptive behaviors, respectively), it is not appropriate to use this terminology when describ- ing pseudosexual behaviors. Because males usually do not occur in unisexual organisms, the terms male-like and female-like are used to refer to these pseudosexual behaviors.

It is remarkable that both the sexual and the unisexual species of whiptail lizard exhibit a similar "mating"' sequence (Figure 2). In the two parental gonochoristic species, the male approaches and investigates the female with his bifid tongue, presumably indicating involvement of chemical senses via the vomeronasal organ. A sexually receptive female stands still for the male, allowing him to mount her back. Usually just before the male mounts the female, he grips with his jaws either a portion of the skin on the female's neck or her foreleg. As the male rides the female, he scratches her sides and presses the female's body against the substrate. The male then begins to maneuver his tail beneath the female's tail, attempting to appose their cloacal regions. During mating, one of two

\section{C. inornatus}
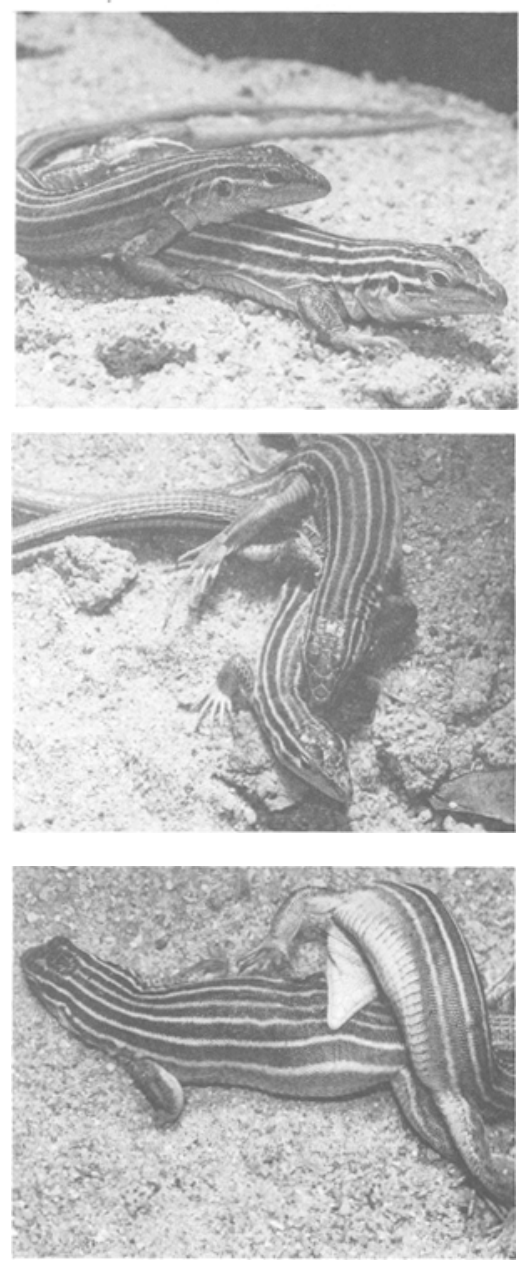

\section{C. uniparens}
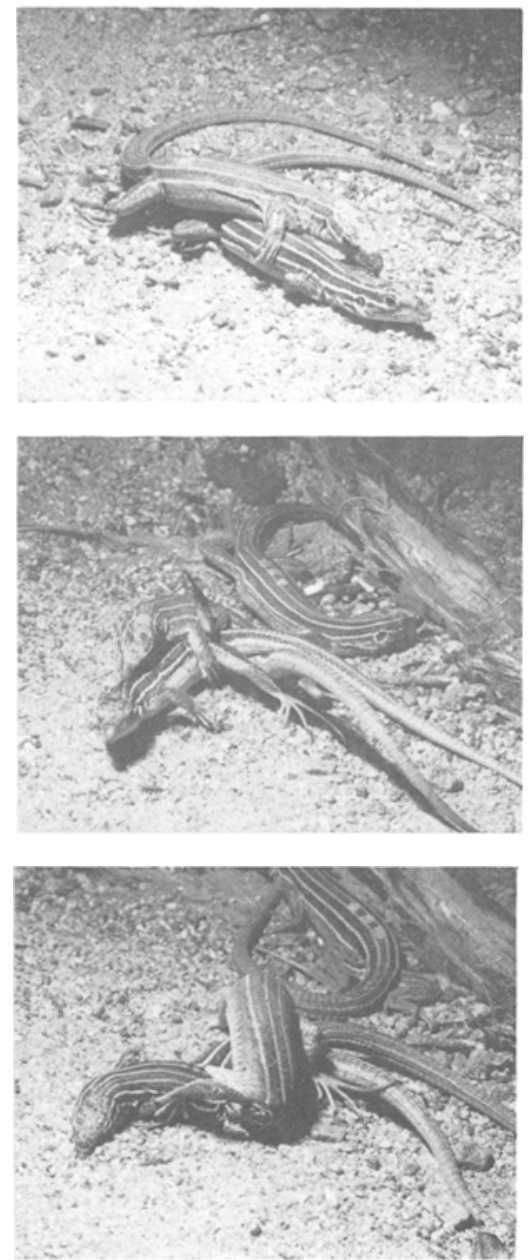

C. gularis
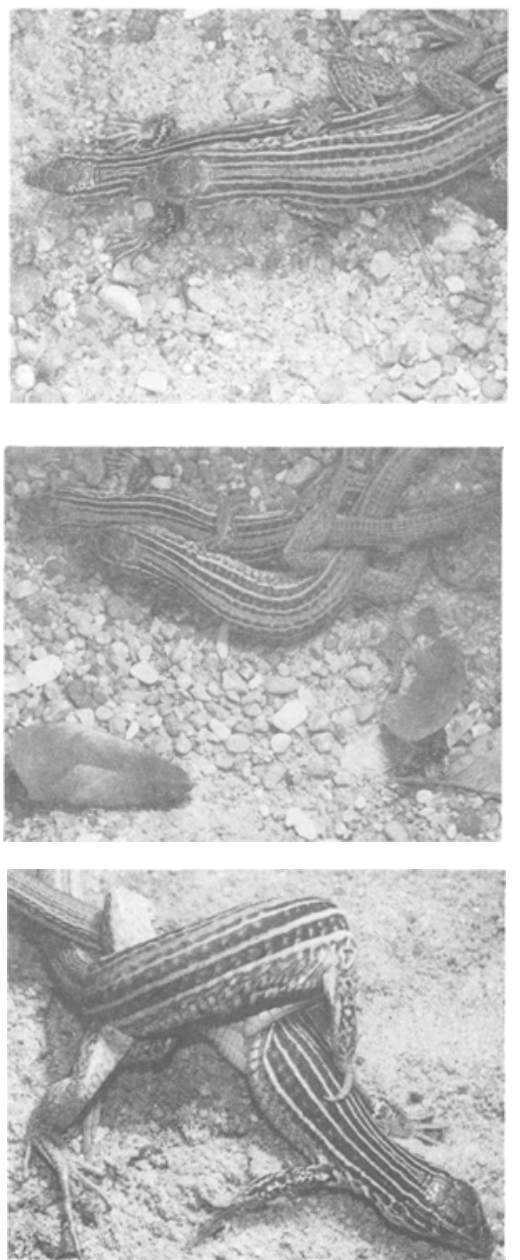

Figure 2. Sexual and pseudosexual behavior in whiptail lizards. Mating sequence in the ancestral, sexually reproducing whiptail lizards, Cnemidophorus inornatus (left panel) and C. gularis (right panel). Photos by P. DeVries. Middle panel: Pseudosexual behavior in the descendant, parthenogenetic whiptail lizard, $C$. uniparens. Photos by D. Crews. Note the similarity in the behavioral sequence to that of the gonochoristic whiptail species. 
hemipenes is everted through the male's cloacal opening and is intromitted into the female's cloaca. With intromission, the male shifts his jaw-grip from the female's neck to her pelvic region, thereby assuming a contorted copulatory posture, which I call the doughnut posture. This posture is maintained for $5-10 \mathrm{~min}$, after which the male rapidly dismounts and leaves the female.

A virtually identical sequence of events has been observed in at least five species of unisexual whiptail lizards (Crews \& Fitzgerald, 1980) (see Figure 2). One individual approaches and mounts another individual. After riding for a few minutes, the mounting (male-like) individual swings its tail beneath that of the mounted (female-like) individual, apposing the cloacal regions. At the same time, the mounting individual shifts its jaw-grip from the neck to the pelvic region of the mounted individual, assuming the doughnut posture. Since the parthenogens are morphologically female, there are no hemipenes and intromission does not occur. Although this phenomenon has been studied only in captivity, mounting behavior has been observed in the field (Grassman \& Lindzey, 1986). Similarly, pseudocopulatory behaviors have been reported in field studies of the parthenogenetic morning gecko, Lepidodactylus lugubris (Brown, 1987; Crews, 1987c; Falanruw, 1972; Werner, 1980; Zaworski, 1987).

\section{The Psychobiology of Sexual and Pseudosexual Behavior}

It is well established that in gonochoristic vertebrates, the courtship and copulatory behavior of the male facilitates ovarian growth in conspecific females, in addition to ensuring fertilization of female ova by male sperm. Indeed, studies with representatives of all vertebrate classes show that the sexual behavior of the male facilitates the environmental stimulation of ovarian recrudescence in the female (Crews \& Silver, 1985). For example, in the musk shrew (Dryden, 1969), ring dove (Lehrman, 1965), green anole lizard (Crews, 1975), rough-skinned newt (Moore, 1987), goldfish (Stacey, 1987), and some coral reef fishes (Demski, 1987), the courtship behavior of the male synchronizes and coordinates the reproductive physiology of the female. Often the female does not undergo normal ovarian development in the absence of sexually active males. In Cnemidophorus inornatus, the maternal ancestor to $C$. uniparens, the courtship behavior of a sexually active male is required for reproduction in the female (Crews, Grassman, \& Lindzey, 1986). Thus, this behavioral facilitation of reproduction in gonochoristic vertebrates represents a potent selection pressure favoring maintenance of male-typical behaviors.

Pseudosexual behavior in the descendant unisexual species serves a function similar to that of male courtship stimulation of female ovarian growth in gonochoristic species. Isolated parthenogens may eventually ovulate, but if other reproductively active individuals are present, more will ovulate sooner (Crews et al., 1986). Furthermore, if the cagemate is treated with progesterone, the hormone responsible for inducing male-like pseudocopulatory behavior (see below), the latency to ovulation is shortened considerably (Crews et al., 1986). This behavioral facilitation of ovarian growth also results in the production of many more eggs during the course of the breeding season. In nature, $C$. uniparens lay between 2 and 3 clutches per breeding season (Congden, Vitt, \& Hadley, 1978; Hulse, 1981). In captivity, isolated individuals lay viable eggs, but the social environment has a pronounced effect on fecundity. Isolated individuals lay an average of 0.8 clutches, whereas individuals housed with conspecifics displaying male-like pseudosexual behavior lay an average of 2.5 clutches (Crews \& Moore, in press; Gustafson \& Crews, 1981). Thus, only those captive individuals able to engage in pseudosexual interactions exhibit normal fecundity. Furthermore, housing intact individuals together leads to a complementarity in their reproductive conditions and an alternation in their roles in pseudosexual encounters. For example, if two intact individuals are housed together, they quickly become $180^{\circ}$ out of phase with one another in terms of both their ovarian activity and their behavior (Crews \& Fitzgerald, 1980; Moore, Whittier, Billy, \& Crews, 1985). Behavioral facilitation of reproduction also occurs in the parthenogenetic gecko, L. lugubris (Brown \& Sakai, in press; Falanruw, 1972).

\section{The Reproductive Endocrinology of Sexual and Unisexual Whiptail Lizards}

In females of all vertebrates studied to date, the circulating levels of estrogen increase as the follicle grows, peaking around the time of ovulation (reviewed in Crews \& Silver, 1985). Progesterone levels begin to increase during the latter stages of follicular maturation and reach their maximum following ovulation; progesterone concentrations decline as the corpora lutea are resorbed. In some species, the androgenic hormones are low throughout the ovarian cycle (as is the case in the whiptail lizards), whereas in others, androgens are elevated during the follicular phase, the luteal phase, or in both. Similarly, in male vertebrates exhibiting an associated reproductive pattern (Crews, 1984), concentrations of androgens such as dihydrotestosterone and testosterone are highest during the breeding season while estrogen and progesterone secretions are low and monotonic (Crews \& Silver, 1985).

The reproductive cycles of both female sexual whiptail lizards and the parthenogenetic whiptails consist of a series of discrete ovarian cycles, each approximately 3-4 weeks in duration; both ovaries simultaneously ovulate one to two eggs each (Moore, Whittier, \& Crews, 1985). Following ovulation, corpora lutea form in the ovary and the ova pass into the oviducts, where shell deposition occurs. Shelled eggs are usually laid 7-10 days after ovulation. Production of a second clutch may be initiated within several days of oviposition. Experiments reveal further that the temporal patterns of ovarian hormone secretion are indistinguishable in the sexual and parthenogenetic whiptail lizard species. 


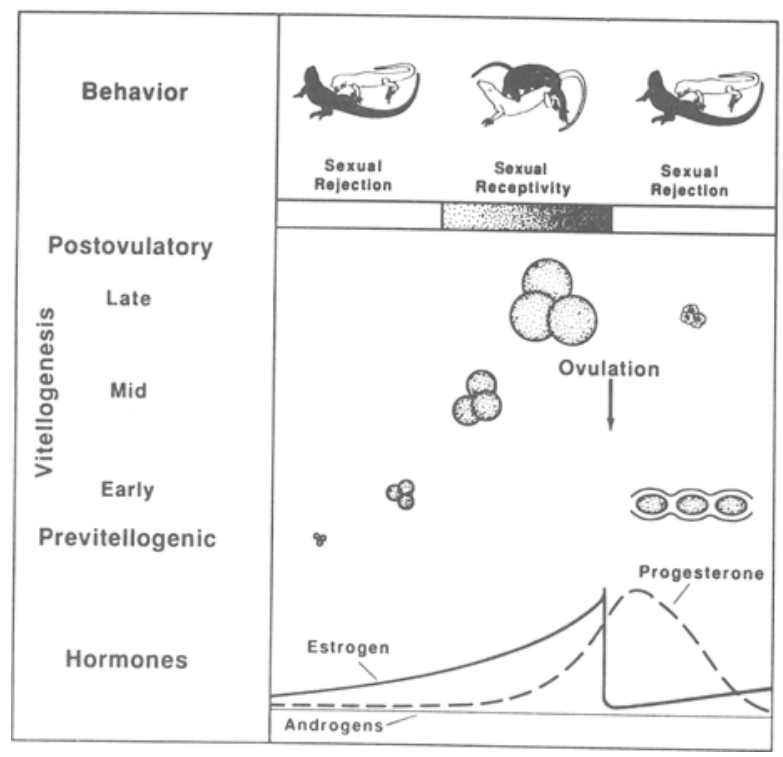

Figure 3. Relation among sexual and aggressive behavior, circulation concentration of sex steroid hormones, and ovarian state in the female whiptail lizard, Cnemidophorus inornatus.

In the maternal ancestral species, $C$. inornatus, hormonal fluctuations have predictable effects on sexual behavior. In females, the receptive and aggressive behaviors vary with the stage of the ovarian cycle (Lindzey \& Crews, 1988) (see Figure 3); sexual receptivity is exhibited only in the preovulatory stage, whereas previtellogenic and gravid females are highly aggressive. In males, courtship and copulatory behavior occurs only when circulating levels of testosterone and dihydrotestosterone are elevated, progesterone is low but unvarying, and estrogen is undetectable (Moore \& Crews, 1986). As is the case with female sexual receptivity, male courtship and copulatory behavior is dependent upon gonadal steroid hormones. Castrated males do not court females, but treatment of castrates with exogenous androgens reinstates courtship and copulatory behavior (Lindzey \& Crews, 1986). Significantly, about one-third of the castrates respond with complete sexual behavior following administration of exogenous progesterone (Lindzey \& Crews, 1988). It is important to note that progesterone-sensitive males actively court and copulate with females with an intensity equal to that shown by androgen-treated castrates. This suggests that $C$. inornatus is polymorphic in the character of a behavioral (i.e., brain) sensitivity to progesterone.

This finding of a polymorphism in the hormonebehavior relationship in the sexual ancestral species is exciting for two reasons. First, it is completely opposite that found in studies on domesticated rodents and birds (reviewed in Lindzey \& Crews, 1986, in press). In these species, progesterone is an effective suppressor of sexual behavior in males. That is, administration of exogenous progesterone to sexually active males reduces the frequency and intensity of sexual behavior; when given in conjunction with androgen to castrated males, sexual behavior is not reinstated. The second reason this polymorphism in sensitivity to progesterone is of interest is that it may constitute an exaptation (Gould \& Vrba, 1982), or a feature that arose for one purpose but has been coopted during evolution to serve another purpose.

The pseudosexual behavior of the parthenogen is also related to physiological state (Crews, 1987a) (see Figure 4). Female-like behavior is limited to the preovulatory stage of the follicular cycle, whereas male-like behavior occurs most frequently during the postovulatory stages of the cycle. As might be expected, these behavioral roles during pseudocopulations are paralleled by differences in the circulating levels of sex steroid hormones

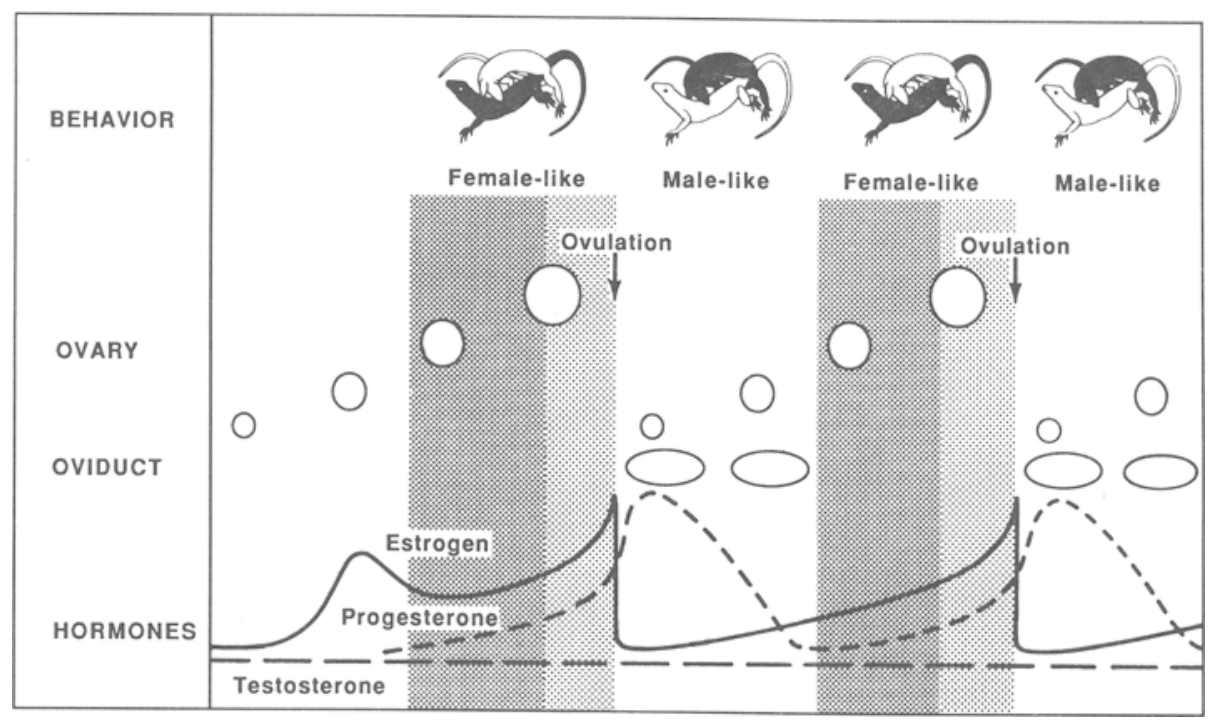

Figure 4. Relation among male-like and female-like pseudosexual behavior, ovarian state, and circulating concentrations of sex steroid hormones during different stages of the reproductive cycle of parthenogenetic Cnemidophorus uniparens. 
produced by the ovary. Individuals show primarily female-like behavior during the preovulatory stage, when plasma estradiol levels are relatively high and progesterone levels relatively low. Male-like behavior is seen usually in the postovulatory phase, when estradiol levels are low and progesterone levels have increased.

The ancestral and descendant species are alike in that they are androgen-sensitive. Administration of exogenous androgens stimulates development of secondary sex characters both early and late in development in both parthenogenetic and gonochoristic whiptail species (Crews, 1987a; Billy \& Crews, 1986; Crews, Gustafson, $\&$ Tokarz, 1983). For example, male-like pseudosexual behavior can be induced readily in either intact or ovariectomized parthenogens by hormone treatment. Reflecting their sexual ancestry, parthenogens respond to exogenous testosterone or dihydrotestosterone treatment (Crews et al., 1983; Crews \& Moore, in press; Gustafson \& Crews, 1981). However, radioimmunoassay of circulating concentrations has uniformly failed to detect plasma levels of these androgens at any stage of the reproductive cycle (Moore, Whittier, Billy, \& Crews, 1985). Not only is there no evidence for transient surges in plasma androgens during the course of the ovarian cycle, but individuals exhibiting male-like pseudosexual behavior are no more likely to have detectable levels of testosterone or dihydrotestosterone than are lizards exhibiting female-like pseudosexual behavior. Thus, the parthenogens have retained their sensitivity to androgens, but do not appear to secrete detectable amounts of androgens.

Other observations support the conclusion that pseudocopulatory behaviors in unisexual whiptails depend on steroid hormones, albeit not on androgens. First, pseudocopulatory behaviors have never been observed in reproductively inactive individuals or in ovariectomized individuals. Second, whereas female-like behavior is almost completely restricted to the yolk deposition phase, male-like behavior is most frequent in postovulatory, gravid animals. Third, the frequencies of male-like and female-like pseudosexual behaviors exhibited by an individual change reliably during the course of the ovarian cycle, with the result that two individuals alternate in both their physiology and their behavior.

There are several possible means by which steroid hormones regulate pseudosexual behavior. First, the nature and pattern of ovarian hormone secretion could have been altered during the evolution of the parthenogen such that a sex steroid hormone profile characteristic of males resulted, thereby accounting for the expression of the male-like pseudocopulatory behaviors. Second, progesterone, the precursor of all androgens, might be converted to androgens in their target tissues in the brain, exerting its effect by serving as a prohormone. Third, the neural mechanisms subserving male-typical and female-typical sexual behaviors in the sexual ancestors could have been retained, but, in the absence of physiological levels of androgen, co-opted another physiological and/or environ- mental stimulus to trigger male-like pseudosexual behaviors.

The close parallels in the nature and pattern of sex steroid hormone secretion in females of the sexual species and the parthenogens indicate that the evolution of parthenogenesis has not been accompanied by an alteration of the usual pattern of endocrine changes. Although the second alternative remains a possibility, recent experiments supporting the third alternative appear to exclude the second as a possibility.

It is a truism that behavioral transitions commonly occur at transitions in hormone concentrations in the blood. There is an intriguingly close parallel between the transition from female-like to male-like pseudosexual behavior and the three-fold decrease in circulating levels of estradiol and the nine-fold rise in progesterone levels at ovulation (Figure 4). Is it possible that this shift in hormone concentrations plays a crucial role in controlling expression of pseudosexual behavior? Recent experiments suggest that the postovulatory surge in progesterone has been exploited to serve as the trigger for male-like behavior in the parthenogen. Recalling that ovariectomy abolishes all pseudocopulatory behavior in parthenogens, I thought that if progesterone were adminstered to one individual of a pair and estrogen to the other, pseudocopulations could be induced between two ovariectomized parthenogens. Indeed, pseudocopulations are seen only if one individual of such a pair is treated with progesterone and the other with an estradiol implant; furthermore, the progesteroneimplanted parthenogens always assume the male-like role in the pseudocopulation (Grassman \& Crews, 1986). It is important to note here that other experiments with the sexual ancestral species have found that intact females housed in all-female groups mounted one another, with the male-like individual being postovulatory. Furthermore, administration of progesterone to ovariectomized females has been found to stimulate female-female mounting behavior (Lindzey \& Crews, 1987).

Experiments in which each individual of a dyad was hormone treated (e.g., Grassman \& Crews, 1986; Gustafson \& Crews, 1981) pointed to an important feature of courtship and copulatory behavior. The principle of stimulus-response complementarity (Beach, 1976, 1979) was originally modeled for sexually reproducing species. Briefly, the model suggests that a complementarity must exist between the behavioral stimulus pattern (S) and the behavioral response pattern $(R)$ if animals are to progress through the highly complex interactions required for reproduction. Because the principle of S-R complementarity is independent of genetic and gonadal sex, femaletypical stimuli (in sexually reproducing species) tend to evoke male-typical behavioral responses and male-typical stimuli tend to evoke female-typical responses in both gonadal males and gonadal females. For example, Beach visualized this relationship as the mounting (S) of one individual requiring the receptivity $(R)$ of the other individual if mating was to occur. It is evident that this con- 
cept applies to asexual organisms as well. Although originally restricted to organismal behavior, I believe this principle also has applicability to other levels of biological organization where elements have co-evolved (e.g., hormone-receptor relationships).

\section{Brain Mechanisms Controlling Sexual and Pseudosexual Behavior}

If the behaviors of the sexual ancestor and the parthenogenetic descendant are similar in form and in function, are the neuroendocrine mechanisms underlying these behaviors also the same? It appears that the neural circuits utilized are similar, yet the hormonal cues that initiate sexual versus pseudosexual behavior are different.

There appear to be two distinct neural circuits that mediate sexual behaviors in vertebrates. Studies on representative species of all vertebrate classes agree in that portions of the anterior hypothalamus and preoptic area (AH-POA) are involved in the control of mounting and intromission behavior, whereas portions of the ventromedial hypothalamus (VMH) are involved in sexual receptivity (Crews \& Silver, 1985; Pfaff \& Schwartz-Giblin, 1988; Sachs \& Meisel, 1988). The neurons residing in these areas concentrate sex hormones, and implantation of minute amounts of the appropriate sex hormones directly into these areas of gonadectomized individuals restores mounting and receptive behaviors.

The fact that the parthenogenetic whiptails exhibit malelike mounting and intromission behaviors suggests that the neural circuits underlying these behaviors have been retained. This does not, however, provide the requisite proof of the hypothesis that similar neural areas are employed in the display of pseudosexual behavior. Neuroendocrine studies have determined that similar areas of the brain are involved in the control of male-like pseudocopulatory behavior in the parthenogens and in mounting and intromission behavior in males of the sexual species. This has been shown by two independent methods.

One approach in determining whether the brain areas involved in the display of male-like pseudosexual behavior in the unisexual whiptails are the same as those areas controlling male-typical mounting and intromission behavior in the ancestral sexual species has been the intracranial implantation of steroid hormones. Results to date indicate that androgen implanted into the AH-POA, but not into the $\mathrm{VMH}$, activates mounting behavior in both the parthenogenetic descendant and sexual ancestral species (Mayo \& Crews, 1987; Rozendaal \& Crews, in press)

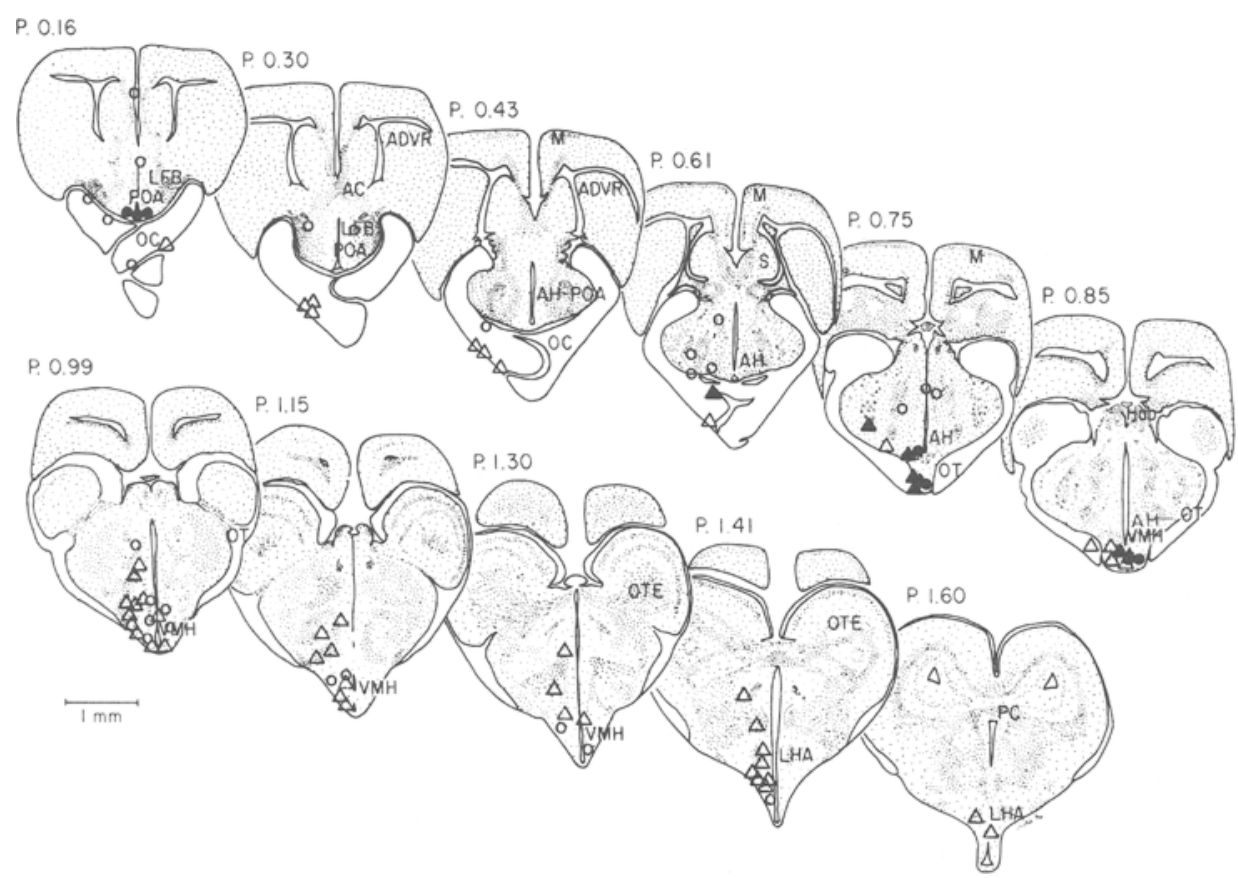

Figure 5. Schematic representation of the placement of hormone implants in the brain that elicited the doughnut copulatory posture in whiptail lizards. Solid triangles indicate androgen implants in studies with the parthenogenetic whiptail lizard, Cnemidophorus uniparens. Solid circles indicate androgen implants in studies with males of the gonochoristic ancestral species, $C$. inomatus. Open symbols represent placement of implants that failed to elicit either male-like pseudocopulatory behavior in $C$. uniparens or maletypical sexual hehavior in $C$. inornatus. In all experiments animals were gonadectomized at least 2 weeks prior to implantation. Numerals indicate distance posterior to zero point. LFB-lateral forebrain bundle; POA-preoptic area; OC-optic chiasm; AC-anterior commissure; ADVR-anterior dorsal ventricular ridge; AH-anterior hypothalamus; OT-optic tract; VMH-ventromedial hypothalamus; OTE-optic tectum; PC-posterior commissure; LHA-lateral hypothalamic area. 
(see Figure 5); implantation of progesterone into the AH-POA, but not into the VMH, of the unisexual descendant elicits male-like behavior (Crews \& Mayo, 1986). The mechanisms controlling receptive behavior involve the VMH: when implanted into the VMH, but not into the AH-POA, estrogen activates receptivity in $C$. uniparens; estrogen has no effect on the display of male-like behavior (Wade \& Crews, 1988).

Another approach for investigating the brain mechanisms controlling species-typical behavior is to study the hormone-receptor interaction directly. Although experiments indicate that the ancestral and descendant species share similar neural circuits that control mounting behaviors and, furthermore, that these neural circuits are responsive to both androgen and progesterone, this is not evidence that the two hormones act via the same hormone receptors.

There are several possible explanations for the observed progesterone effects in whiptails. It is well established that progesterone can mimic the actions of androgens by binding to androgen receptors in the cell and translocating to the nucleus (Bardin, Brown, Isomaa, \& Jänne, 1984). Recall that the functional outcome of progesterone binding to androgen receptors in mammals and birds is to inhibit sexual behavior in males. In progesterone-sensitive male $C$. inornatus, however, progesterone stimulates sexual behavior. What is happening at the genomic level that could account for these results? It is possible that the hormonal specificity, but not the neural circuits themselves, has changed. For example, it is possible that in the parthenogenetic whiptail, progesterone activates male-like behavior by binding to androgen receptors that were retained along with the neural circuits that control mounting behavior. This hypothesis is attractive, because the almost complete lack of circulating androgen in the parthenogen would allow binding of even relatively weak agonists (e.g., progesterone) to androgen receptors.

Another possibility is that progesterone acts by binding to progesterone receptors that are functionally linked to the neural circuits that control sexual behavior in males of the ancestral species. This is supported by the finding that administration of R5020, a synthetic progestin, completely restores homotypical sexual behavior in castrated, progesterone-sensitive males (Lindzey \& Crews, in press). Furthermore, administration of RU 486, an antiprogestin, to androgen-treated castrates fails to inhibit the restoration of sexual behavior, yet prevents the induction of sexual behavior in progesterone-sensitive males by progesterone (Lindzey \& Crews, in press). This suggests that progesterone acts directly as a progestin in stimulating mounting behavior. Present efforts are focused on identifying and characterizing the progesterone and androgen receptor systems in the brain.

If progesterone proves to act through its own receptors, this will suggest that the progesterone receptor and androgen receptor overlap in their abilities to bind to and regulate specific regions on the genome responsible for stimulation of specific behavior patterns. This functional overlap might be the result of homology between the chromatin binding regions of the two receptors or the result of similar acceptor regions within the genome. If, on the other hand, progesterone proves to act through the androgen receptor, this would suggest a fundamental difference in the mechanisms of hormone action at the genomic level in the whiptail lizards compared with all other vertebrates studied to date.

\section{GENDER AS CHROMOSOMES}

Basic research on the mechanisms underlying sex determination and sexual differentiation, mostly in domesticated and inbred vertebrate species, has revealed that upon fertilization, the genetic constitution of the individual is fixed. Thus, males and females differ at a fundamental genetic level. In mammals, the individuals we refer to as "males" have a dissimilar pair of chromosomes (XY), whereas "females" have a similar pair of chromosomes $(\mathrm{XX})$; in birds, the opposite pertains, whereas in some reptiles, amphibians, and fish the heterogametic sex can vary depending on the species (Bull, 1983). The determination of genotype, in turn, results in the differentiation of the gonads, initiating a cascade of events that sculpt the differences between males and females. For example, the hormones secreted by the newly differentiated ovaries and testes are critical to the differentiation of accessory sex structures and secondary sex characters, including the brain. Sexually dimorphic adult organisms that must mate to contribute their genes to the next generation are the end result.

In all mammals and birds and in some reptiles, gonadal differentiation is a consequence of genotypic sex determination (GSD) mechanisms. In some reptiles, however, sex is determined by environmental sex determination (ESD) mechanisms (Bull, 1983). The fundamental difference between GSD and ESD mechanisms lies in the trigger that initiates sex determination: in the former, gonadal sex is determined at fertilization by the pairing of homologous chromosomes, whereas in the latter, gonadal sex is determined later in embryogenesis as a consequence of the embryo's environment (Figure 6). They are alike,

ENVIRONMENTAL SEX DETERMINATION

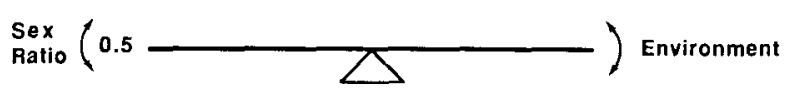

GENOTYPIC SEX DETERMINATION

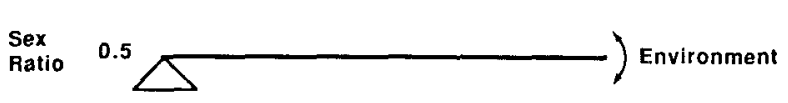

Figure 6. A schematic representation of the fundamental difference between environmental sex determination and genotypic sex determination. 
Determination of Gonadal Sex

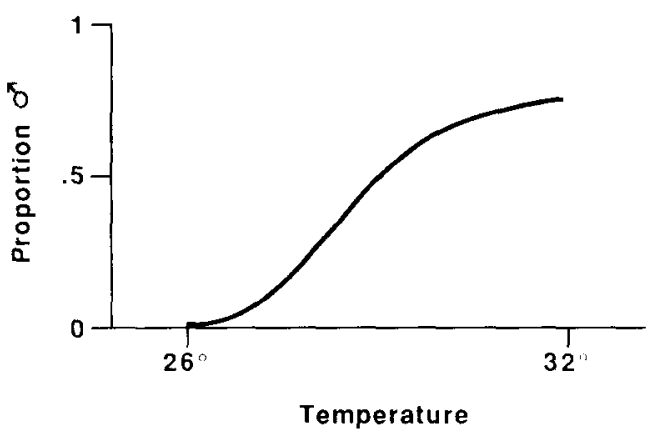

Figure 7. Effect of temperature on primary sex ratio in the leopard gecko, Eublepharis macularius.

however, in that in both, (1) the primary sex determiner operates solely as a trigger that initiates the events that shape sex differences, (2) hormones secreted by the embryonic gonad govern the subsequent differentiation and development of other components of sexuality (Crews \& Bull, 1987; Wilson, George, \& Griffen, 1981), and (3) intersexes or hermaphrodites are usually not found. Study has revealed that all ESD species appear to be gonochoristic, lack heteromorphic sex chromosomes, and have little if any genetic control over the determination of gonadal sex (Bull, 1983). Furthermore, Bull and coworkers have recently found that the putative testis determining gene of mammals (Page et al., 1987) hybridizes to DNA of both males and females in ESD reptiles (Bull, Hillis, \& O'Steen, 1988). Thus, species exhibiting ESD present researchers with an opportunity to examine the extent to which sexual dimorphisms are independent of genotype. In such species, there is no male or female genome established at fertilization; rather, the determination of gonadal sex is triggered strictly by an environmental stimulus.

\section{The Leopard Gecko}

The most thoroughly studied ESD system is temperature-dependent sex determination (Bull, 1980). For example, in the leopard gecko (Eublepharis macularius), gonadal sex is determined by incubation temperature, with relatively "hot" temperatures $\left(32^{\circ} \mathrm{C}\right)$ resulting in $80 \%$ male offspring and $20 \%$ female offspring, whereas relatively "cool" temperatures $\left(26^{\circ} \mathrm{C}\right)$ result in only female offspring (Figure 7); the primary sex ratio is $50: 50$ at the intermediate temperature of $29^{\circ} \mathrm{C}$. It is important to note that intersexes are not produced (Bull, 1987; Wagner, 1980), and that even at the high incubation temperatures, the gonads of female individuals are clearly ovaries (Figure 8). Histological examination of the ovaries of females from hot incubation conditions (hereafter hot females) has not revealed any evidence of testicular fragments or cells. There are no evident differences between the ovaries of hot females and the ovaries of females from cold incubation conditions (hereafter cold females).

\section{The Effects of Incubation Temperature on Adult Sexuality}

Incubation temperature of the embryo affects sexual dimorphisms in the adult phenotype. Secondary sex characters in the leopard gecko include head dimensions,
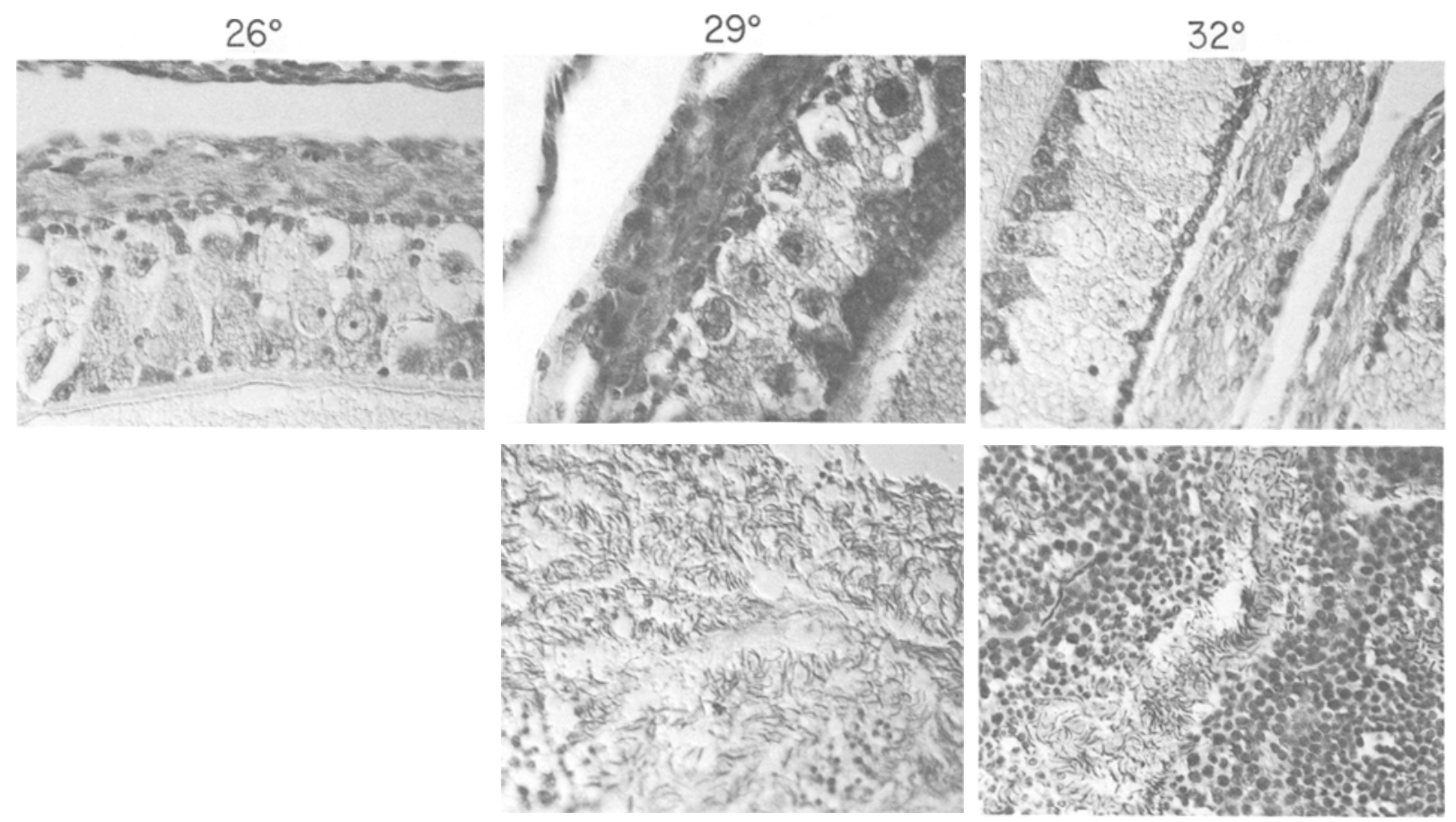

Figure 8. Histology of gonads of adult leopard geckos that had been incubated at $26^{\circ}, 29^{\circ}$, or $32^{\circ} \mathrm{C}$. Top panel are ovaries, bottom panel are testes. Intersexes have never been observed. Photos by J. LaClaire. 


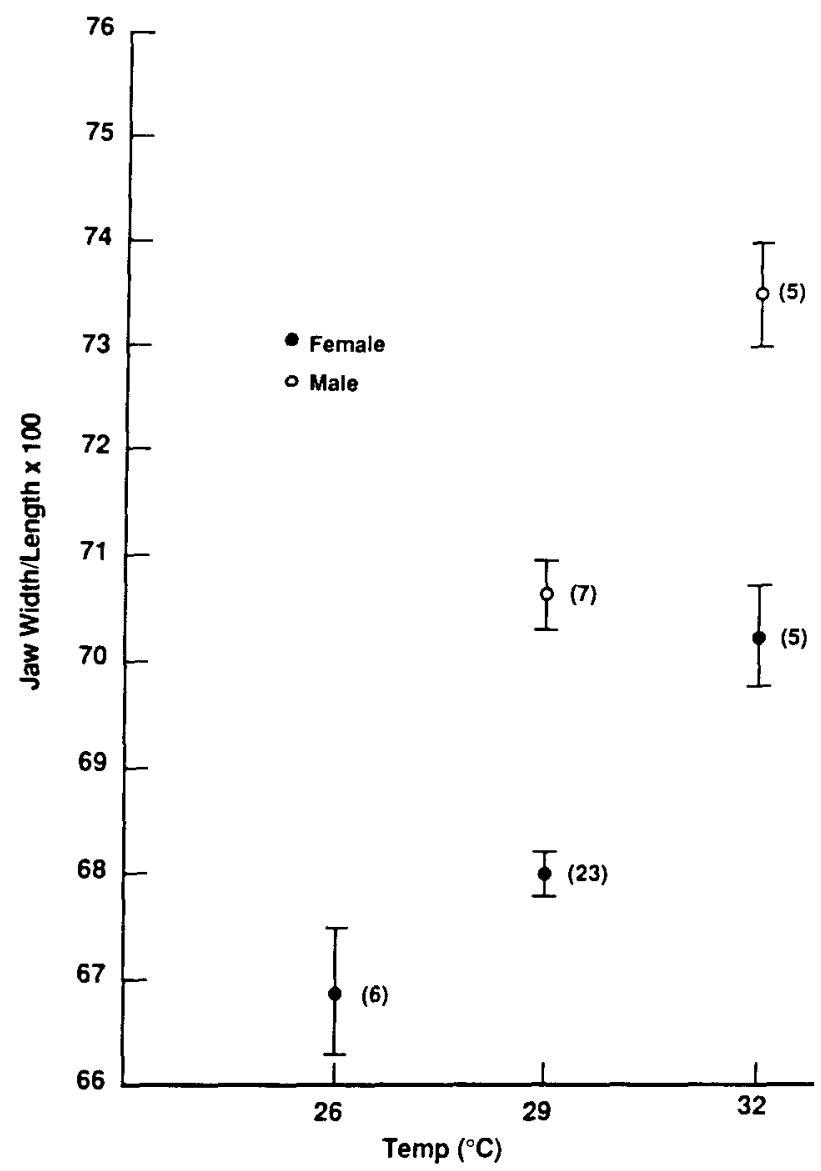

Figure 9. Effect of incubation temperature on head size in male and female leopard geckos. Presented are the means and standard errors for adults of known incubation temperatures. Sample sizes shown in parentheses.

patent pubic pores, and cloacal swelling due to the hemipenes. With the exception of cloacal swelling (females have never been observed to have hemipenes), these meristic characters vary within each sex according to incubation temperature. Females from eggs incubated at $32^{\circ} \mathrm{C}$ (hot females) have pronounced pubic glands with patent pores similar to those found in males; females from eggs incubated at $26^{\circ} \mathrm{C}$ (cold females) and $29^{\circ} \mathrm{C}$ have smaller glands and closed pores (Gutzke \& Crews, 1988). Head size also is sexually dimorphic in the leopard gecko. However, for a given sex, individuals from hot incubation temperatures had significantly wider heads than those from cold incubation temperatures (Figure 9).

The endocrine physiology of the adult is also influenced by the temperature experienced during incubation. Radioimmunoassay of circulating concentrations of sex steroid hormones reveals systematic differences in the levels of total androgens and estradiol both between and within the sexes (Gutzke \& Crews, 1988) (see Table 1). Overall, circulating concentrations of total androgens in adult females are lower than in adult males; levels of estrogen do not differ between the sexes. No significant differences are detected in the hormonal profiles of males from eggs incubated at different temperatures. However, androgen levels are significantly higher and estrogen levels lower in hot females compared with cold females.

Based on the above information, one might predict that psychosexual differentiation in the sexes might also be influenced by events in the eggs (Figure 10). Indeed, the sexual behavior of adult females varies according to the temperature they experienced in the egg.

Sexual behavior in leopard geckos is stereotyped and differs between the sexes. The typical copulatory sequence consists of the male's rapidly vibrating his tail on encountering a female; females have never been observed to exhibit this behavior. It is assumed that tail wagging is elicited by the detection of a female-specific pheromone (Mason \& Gutzke, 1988). Males also rub the pubic area against the substrate, presumably depositing pheromone(s) in the exudate from the pubic pores. The male then approaches the female and licks her tail. The male next grips and shakes the female's tail; this biting and shaking is gentle and does not result in any discemible wounds. The male then shifts his jaw-grip to the female's back, neck, or head area, moving his body parallel to the female's body. Again, this biting is very gentle. At this point, the female usually raises her tail and allows the male to appose his cloacal region to hers, and intromission occurs.

A receptive female remains stationary as a courting male first licks and then grips her tail. As the male shifts his grip to the female's back, neck, or head area, the female raises her tail and allows intromission. A nonreceptive female may terminate courtship at any point by either fleeing from the male, biting the male (generally causing tissue damage), throwing the male off her back, or displaying heterotypical (male-typical) behavior.

Although all of the females tested to date have elicited comparable levels of courtship from male stimulus animals, indicating that males do not discriminate among them, the responses of females to male courtship differ markedly depending upon the female's incubation temperature (Gutzke \& Crews, 1988) (see Figure 11). If she is receptive, a cold female exhibits only sexual receptivity when courted by a male; no heterotypical behaviors are

Table 1

Circulating Concentrations of Total Androgens and Estradiol as Measured by Radioimmunoassay in Adult Leopard Geckos (Eublepharis macularius)

\begin{tabular}{|c|c|c|c|c|c|}
\hline \multirow{2}{*}{$\begin{array}{l}\text { Incubation } \\
\text { Temperature }\end{array}$} & \multirow[b]{2}{*}{ Number } & \multicolumn{2}{|c|}{$\begin{array}{c}\text { Total } \\
\text { Androgens }\end{array}$} & \multicolumn{2}{|c|}{ Estradiol } \\
\hline & & $M$ & $\overline{S D}$ & $M$ & $S D$ \\
\hline \multicolumn{6}{|c|}{ Female } \\
\hline $26^{\circ} \mathrm{C}$ & 4 & 0.36 & 0.07 & 0.88 & 0.13 \\
\hline $29^{\circ} \mathrm{C}$ & 7 & 1.23 & 0.45 & 0.49 & 0.05 \\
\hline $32^{\circ} \mathrm{C}$ & 5 & 6.06 & 2.11 & 0.41 & 0.10 \\
\hline \multicolumn{6}{|c|}{ Male } \\
\hline $29^{\circ} \mathrm{C}$ & 6 & 77.92 & 26.40 & 0.48 & 0.06 \\
\hline $32^{\circ} \mathrm{C}$ & 9 & 31.67 & 4.33 & 0.37 & 0.04 \\
\hline
\end{tabular}

Note-Mean concentration in $\mathrm{ng} / \mathrm{ml}$ is presented with \pm 1 standard error (see Gutzke \& Crews, 1988). 
Determination of Behavioral Sex

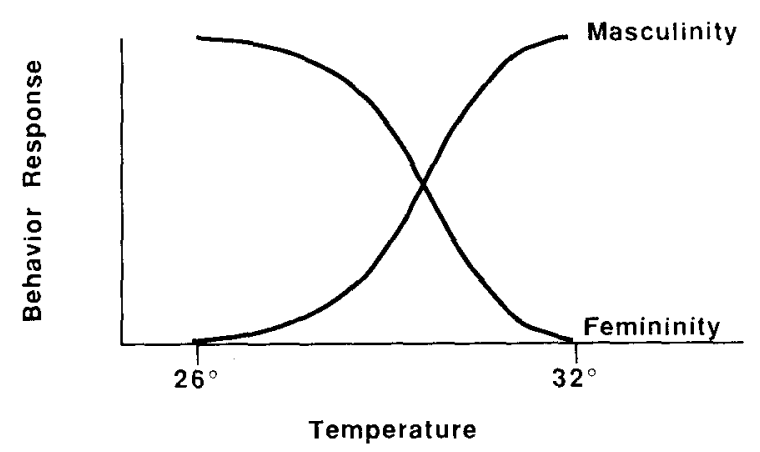

Figure 10. Hypothetical model of adult psychosexual sexual differentiation of gonadal female leopard geckos incubated at different temperatures. See text for further details. observed. Hot females, however, respond frequently with heterotypical behaviors; that is, these females respond to male courtship as if they themselves are males. This suggests that it is the female's perception of self, and not her appearance to others or her willingness to mate, that has been influenced by incubation temperature. It is interesting to note that over a 2-year period, no hot female has been observed to mate or lay eggs. Hot females appear to be functionally sterile, but the level at which the sterility occurs (gonad and/or brain) remains to be determined. In mammals, administration of androgen to neonatal females results in a functional sterilization due to a masculinization of the neural circuits subserving ovulation (Goy \& McEwen, 1980; Yahr, 1988). It is possible that in adult geckos, the temperature during incubation determines the sex steroid hormones produced during gonadal differentiation, and results in the observed differences in reproductive behavior.

A

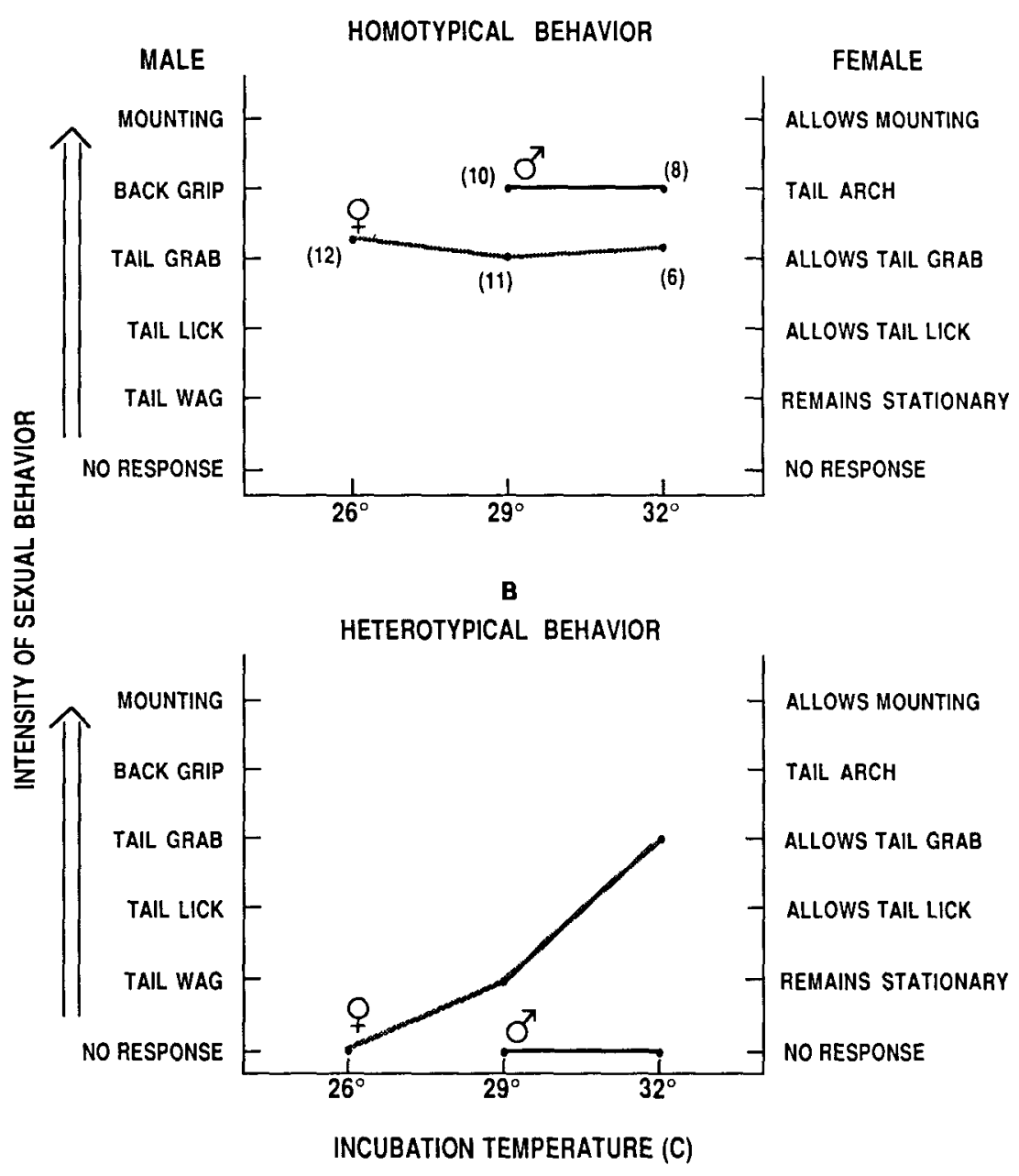

Figure 11. Effect of incubation temperature on psychosexual differentiation in the leopard gecko. Presented are the average median behavioral responses of adult leopard geckos in tests with both male and female stimulus animals. (A) Homotypical response refers to sexual behaviors typical of individuals of the same gonadal sex. (B) Heterotypical response refers to sexual behaviors characteristic of individuals of the opposite gonadal sex. Sample sizes are in parentheses. 
There were no differences in the frequencies of homotypical or heterotypical behavior in males from different incubation temperatures in response to both male and female stimulus animals (Gutzke \& Crews, 1988) (see Figure 11). Males are produced over a smaller range of temperatures than are females $\left(3^{\circ}\right.$ versus $6^{\circ} \mathrm{C}$ ) (see Figure 7 ), and this may be why less behavioral variation is observed.

Agonistic behavior in both sexes also is affected by incubation temperatures. Both males and females are more likely to exhibit aggressive behavior if they experienced high temperatures during incubation; this relation is found whether animals were tested in their home cage or in a neutral site (Gutzke \& Crews, 1988). Incubation temperature also affects the probability of aggressive behavior by males toward other males, but not toward females. However, hot females are equally aggressive toward either sex.

\section{CONCLUSIONS}

I have discussed two animal model systems that give new perspectives on fundamental problems in sexdifferences research. The first animal model system, the parthenogenetic whiptail lizards, illustrates a way of examining the neural and endocrine correlates of sexual behaviors that are not possible in mammals. The parthenogenetic whiptail lizard does not need a male to reproduce, yet it continues to exhibit both male-like and female-like pseudosexual behaviors. The fact that the neural substrates of pseudocopulatory behavior did not originate in unisexual whiptails, but were retained from their sexual ancestors, reflects in part the organization of the vertebrate brain, with its dual neural substrates for mounting and receptive behaviors.

This animal model system also suggests how neuroendocrine mechanisms that control complex behaviors may evolve. The parthenogenetic whiptails do not secrete detectable concentrations of androgen, so some other cue must trigger the male-like pseudocopulatory behavior. This hormonal cue is probably the postovulatory surge of progesterone. In the ancestral sexual species, courtship and copulatory behavior in males is dependent upon testicular androgens, yet some males are behaviorally sensitive to progesterone. This feature of the brain of the ancestral species, in this instance a sensitivity to progesterone of the neuroendocrine mechanisms subserving mounting and intromission behavior, has been co-opted in the descendant species in the form of a novel hormone-brain behavior relationship. That is, this polymorphism in progesterone sensitivity may have been the substrate on which selection acted.

Finally, research on the unisexual lizards illustrates nicely the complementarity at both the behavioral and physiological levels (Beach, 1976, 1979). The apparently universal requirement that females must be stimulated by the behaviors typical of males of their species to show normal ovarian growth (and vice versa) indicates this prin- ciple of complementarity exists at an organismal level as well. It is only when such complementarity exists at all levels that mating and reproduction are successful.

The second animal model system, the leopard gecko, is one in which individuals lack a genotypic sexdetermining mechanism. Attempts to alter the primary sex ratio in mammals and birds have been singularly unsuccessful (Charnov, 1982; Kiddy \& Hafs, 1971), the few exceptional cases of naturally occurring sex ratio biases notwithstanding (Hrdy, 1988). The discovery that temperature, an easily regulated stimulus, determines gonadal sex in some reptiles presents a totally new avenue of approach for investigators of sexual differentiation and gender-related behaviors. Temperature, the primary determiner of gonadal sex in this species, also affects different levels of sexuality. The recent demonstration that the morphology, physiology, and psychosexual behavior of adults of both sexes is influenced by the temperature experienced as an embryo indicates that these effects are permanent and profound.

\section{ENVOI}

An evolutionary perspective reveals that at least some of the assumptions in present-day theories of vertebrate sexual differentiation, based on studies of a restricted number of eutherian mammals, may be overly narrow. For example, the classical view is that all somatic sexual dimorphisms, including brain, and hence behavior, result from gonadal hormone production that begins after morphological differentiation of the gonad. Specifically, it is well established from research on eutherian mammals that it is only after gonadal differentiation that the Leydig cells secrete androgen that stimulates the development of the male reproductive tract; the Sertoli cells secrete Mullerian Inhibitory Substance, which inhibits the development of the female reproductive tract (George \& Wilson, 1986; Wilson et al., 1981).

I have discussed how gender is neither behavior nor chromosomes. There also is good reason to suggest that gender is not gonads or hormones. In the tammar wallaby (Macropus eugenii), a metatherian mammal, sexual differentiation of somatic structures begins well before gonad determination (Wai-Sum, Short, Renfree, \& Shaw, 1988). Furthermore, there is evidence that sexual dimorphisms in such species are not dependent on sex steroid hormones; administration of exogenous androgens or estrogens to pouch young fails to stimulate or inhibit development of secondary sex characters (Fadem \& Tesoriero, 1986; Renfree, Short, \& Shaw, 1987). It is of particular interest to see increasing evidence that even in eutherian mammals there are apparent sex differences that precede gonadal differentiation: extragonadal effects of sex chromosomes (Scott \& Holsen, 1977), altered sex ratios of live young after transfer of fast and slow developing mouse embryos (Sellar \& Perkins-Cole, 1987; Tsunoda, Tokunaga, \& Sugie, 1985), and parental inheritance of methylation patterns (Swain, Stewart, \& 
Leder, 1987). Taken together, these results suggest that even in eutherian mammals, there may be genes that are primarily responsible for the differentiation of secondary sex characters, perhaps even in the brain. Further study of "experiments of nature" such as those described here, or study of other as yet unutilized species such as simultaneous and sequential hermaphrodites, will be important to developing more general theories of gender differences in vertebrates.

\section{REFERENCES}

Bardin, C. W., Brown, T., IsomaA, V. V., JänNe, O. A. (1984). Progestins can mimic, inhibit, and potentiate the actions of androgens. Pharmaceutical Therapeutics, 23, 443-459.

BEACH, F. A. (1968). Factors involved in the control of mounting behavior by female mammals. In M. Diamond (Ed.), Perspectives in reproduction and sexual behavior (pp. 83-132). Bloomington: Indiana University Press.

BEACH, F. A. (1976). Sexual attractivity, proceptivity, and receptivity in female mammals. Hormones \& Behavior, 7, 105-138.

BeACH, F. A. (1979). Animal models for human sexuality. In R. Porter \& J. Whelan (Eds.), Sex, hormones and behavior (pp. 113-143). Amsterdam: Excerpta Medica.

BiLly, A. J., \& CREWS, D. (1986). The effects of sex steroid treatments on sexual differentiation in a unisexual lizard, Cnemidophorus uniparens (Teiidae). Journal of Morphology, 18, 129-142.

Brown, S. G. (1987). When is social stimulation important in parthenogenetic lizards-at egg development or at oviposition? Intermational Ethological Conference XX, Madison, Wisconsin. (Abstract)

Brown, S. G., \& SAKAI, T. J. Y. (in press). Social experience and egg development in the parthenogenetic gecko, Lepidodactylus lugubris. Ethology.

BULL, J. J. (1978). Sex chromosome differentiation: An intermediate stage in a lizard. Canadian Journal of Genetics \& Cytology, 20, 205-209.

BuLL, J. J. (1980). Sex determination in reptiles. Quarterly Review of Biology, 55, 3-21.

BulL, J. J. (1983). Evolution of sex determining mechanisms. Menlo Park, CA: Benjamin Cummings.

BULL, J. J. (1987). Temperature-sensitive periods of sex determination in a lizard: Comparisons with turtles and crocodilians. Journal of Experimental Zoology, 241, 143-148.

Bull, J. J., Hillis, D. M., \& O'STEeN, S. (1988). Mammalian ZFY sequence exists in reptiles regardless of sex determining mechanism. Science.

Charnov, E. L. (1982). The theory of sex allocation. Princeton, NJ: Princeton University Press.

Cole, C. J., Lowe, C. H., \& Wright, J. W. (1969). Sex chromosomes in teiid whiptail lizards (genus Cnemidophorus). American Museum Novitates, 2395, 1-14.

Congden, J. D., VitT, L. J., \& Hadley, N. F. (1978). Parental investment: Comparative reproductive energetics in bisexual and unisexual lizards, genus Cnemidophorus. American Naturalist, 112, 509-521.

Crews, D. (1975). Psychobiology of reptilian reproduction. Science, 189, 1059-1065.

CREWS, D. (1984). Gamete production, sex hormone secretion, and mating behavior uncoupled. Hormones \& Behavior, 18, 22-28.

CREWS, D. (1987a). Diversity and evolution of behavioral controlling mechanisms. In D. Crews (Ed.), Psychobiology of reproductive behavior (pp. 88-119). Englewood Cliffs, NJ: Prentice-Hall.

Crews, D. (1987b). Functional associations in behavioral endocrinology. In J. M. Reinisch, L. A. Rosenblum, \& S. A. Sanders (Eds.), Masculinity/femininity: Basic perspectives (pp. 113-126). Oxford: Oxford University Press.

CRews, D. (1987c). [Field notes on the behavioral biology of the morning gecko Lepidodactylus lugubris.] Unpublished raw data.
CREws, D. (in press). Unisexual organisms as model systems for research in the behavioral neurosciences. In R. Dawley (Ed.), Biology of unisexual organisms. Ithaca, NY: Allen Press.

Crews, D., \& Buli., J. J. (1987). Evolutionary insights from reptilian sexual differentiation. In F. P. Haseltine, M. E. McClure, \& E. H Goldberg (Eds.), Genetic markers of sex differentiation (pp. 11-26). New York: Plenum.

CREWS, D., \& BuLL, J. J. (1988). No apparent temperature-dependent sex determination in congeneric sexual and parthenogenetic lizards. Manuscript submitted for publication.

Crews, D., Fitzgerald, K. (1980). "Sexual" behavior in parthenogenetic lizards (Cnemidophorus). Proceedings of the National Academy of Science U.S.A., 77, 499-502.

Crews, D., Grassman, M., \& Lindzey, J. L. (1986). Behavioral facilitation of reproduction in sexual and unisexual whiptail lizards. Proceedings of the National Academy of Science U.S.A., 83, 9547-9550.

Crews, D., Gustafson, J. E., \& Tokarz, R. R. (1983). Psychobiology of parthenogenesis in reptiles. In R. B. Huey, E. R. Pianka, \& T. W. Schoener (Eds.), Lizard ecology (pp. 205-231). Cambridge, MA: Harvard University Press

CREWs, D., \& MAYO, M. (1986). [Preliminary experiments on the effect of intracranial implantation of progesterone on male-like pseudosexual behavior in the unisexual Cnemidophorus uniparens.] Unpublished raw data.

Crews, D., \&oore, M. C. (in press). Psychobiology of reproduction of unisexual whiptail lizards. In J. W. Wright (Ed.), Biology of Cnemidophorus lizards (Los Angeles Natural History Museum, Special Publication No. 3). Los Angeles: Allen Press

CREWS, D., \& Silver, R. (1985). Reproductive physiology and behavior interactions in nonmammalian vertebrates. In N. Adler, D. W. Pfaff, \& R. W. Goy (Eds.), Handbook of behavioral neurobiology (Vol. 7 , pp. 101-182). New York: Plenum.

DAGG, A. I. (1984). Homosexual behavior and female-male mounting in mammals. Mammalian Review, 14, 155-185.

DAWLEY, R. (in press). Biology of unisexual organisms. Ithaca, NY: Allen Press.

DEMSKI, L. S. (1987). Diversity in reproductive patterns and behavior in teleost fishes. In D. Crews (Ed.), Psychobiology of reproductive behavior (pp. 1-27). Englewood Cliffs, NJ: Prentice-Hall.

Densmore, L. D., Moritz, C., Wright, J. W., Brown, W. M. (in press). Mitochondria DNA analyses and the origin and relative age of parthenogenetic Cnemidophorus: Nine sexlineatus group parthenoforms. Evolution.

DRYDEN, G. L. (1969). Reproduction in Suncus murinus. Joumal of Reproduction \& Fertility, 6(Suppl.), 377-396.

FADEm, B. H., \& Tesoriero, J. V. (1986). Inhibition of testicular development and feminization of the male genitalia by neonatal estrogen treatment in a marsupial. Biology of Reproduction, 34, 771-776.

FALANRUW, M.V.C. (1972). Notes on the reproduction of the parthenogenic gecko Lepidodactylus lugubris. Unpublished manuscript.

GEORGE, F. W., \& WILSON, J. D. (1986). Hormonal control of sexual development. Vitamins \& Hormones, 43, 143-196.

Gould, S. J., VRBA, E. (1982). Exaptation-A missing term in evolution. Paleobiology, 8, 4-15.

GoY, R. W., \& MCEWEN, B. S. (1980). Sexual differentiation of the brain. Cambridge, MA: MIT Press.

Grassman, M., \& Crews, D. (1986). Progesterone induction of pseudocopulatory behavior and stimulus-response complementarity in an allfemale lizard species. Hormones \& Behavior, 20, 327-335.

Grassman, M., \& LindzeY, J. (1986). [Field notes on the behavioral biology of the unisexual whiptail Cnemidophorus uniparens.] Unpublished raw data.

Gustafson, J. E., \& CREWS, D. (1981). Effect of group size and physiological state of a cagemate on reproduction in the parthenogenetic lizard, Cnemidophorus uniparens (Teidae). Behavioral Ecology \& Sociobiology, 8, 267-272.

GUTZKE, W. H. N., \& CREWs, D. (1988). Incubation temperature determines adult sexuality in a reptile. Nature, 332, 832-834.

HuLSE, A. C. (1981). Ecology and reproduction of the parthenogenetic lizard Cnemidophorus uniparens (Teiidae). Annals of the Carnegie Museum, 50, 353-369. 
Hrdy, S. B. (1988). Daughters and sons. Natural History, 97, 63-82. Kelley, D. B. (1988). Sexually dimorphic behaviors. Annual Review of Neuroscience, 11, 225-252.

KIDDY, C. A., HAFs, H. D. (1971). Sex ratio at birth-prospects for control. Albany, NY: Boyd Printing.

LehrMan, D. S. (1965). Interaction between internal and external environments in the regulation of the reproductive cycle in the ring dove. In F. A. Beach (Ed.), Sex and behavior (pp. 355-380). New York: Wiley.

LindzeY, J. L., \& CRews, D. (1986). Hormonal control of courtship and copulatory behavior in male Cnemidophorus inornatus, a direct sexual ancestor of a unisexual parthenogenetic lizard. General \& Comparative Endocrinology, 64, 411-418.

LindzeY, J. L., \& CREWS, D. (1987). [Notes on the behavior of captive sexual whiptail lizards (Cnemidophorus inornatus).] Unpublished raw data.

Lindzey, J. L., \& CREws, D. (1988). Psychobiology of sexual behavior in a whiptail lizard, Cnemidophorus inornatus. Hormones \& Behavior, 22, 279-293.

Lindzey, J. L., CRews, D. (in press). Effects of progestins on sexual behaviors in castrated lizards (Cnemidophorus inornatus). Journal of Endocrinology.

LOWE, C. H., \& WRIGHT, J. W. (1966). Evolution of parthenogenetic species of Cnemidophonus (whiptail) lizards in westem North America. Journal of the Arizona Academy of Science, 4, 81-87.

MASON, R. T., \& Gutzke, W. H. N. (in press). Sex recognition in the leopard gecko, Eublepharis macularius (Sauria: Gekkonidae): Possible mediation by skin-derived semiochemicals. Journal of Chemical Ecology.

Mayo, M, \& CREWS, D. (1987). Neural control of male-like pseudosexual behavior in an all-female lizard: Effects of intracranial implantation of sex steroid hormones. Hormones \& Behavior, 21, 181-192.

MOORE, F. L. (1987). Behavioral actions of neurohypophysial peptides. In D. Crews (Ed.), Psychobiology of reproductive behavior (pp. 6187). Englewood Cliffs, NJ: Prentice-Hall.

MoOre, M. C., \& Crews, D. (1986). Sex steroid hormones in naturally breeding populations of a bisexual whiptail lizard, Cnemidophonus inornatus. General \& Comparative Endocrinology, 63, 424-430.

Moore, M. C., Whittier, J. M., Billy, A. J., \& Crews, D. (1985). Male-like behavior in an all-female lizard: Relationship to ovarian cycle. Animal Behaviour, 33, 284-289.

Moore, M. C., Whittier, J. M., \& Crews, D. (1985). Sex steroid hormones during the ovarian cycle of an all-female, parthenogenetic lizard. General \& Comparative Endocrinology, 60, 144-153.

Page, D., Mosher, R., Simpson, E. M., Fisher, E. M. C., Mardon, G., Pollack, J., McGillivray, B., de la Chapelle, A., \& Brown, L. G. (1987). The sex-determining region of the human $Y$ chromosome encodes a finger protein. Cell, 51, 1091-1104.

Pfaff, D. W., \& SchwarTz-Giblin, S. (1988). Cellular mechanisms of female reproductive behaviors. In E. Knobil \& J. D. Neill (Eds.), The physiology of reproduction (Vol. 2, pp. 1487-1568). New York: Raven Press.

Renfree, M. B., Short, R. V., \& Shaw, G. (1987). Sexual differentiation in marsupials. In F. Haseltine, M. McClure, \& E. Goldberg (Eds.), Genetic markers of sex differentiation, (pp. 1-15). New York: Plenum Press.

RozendaAl, J. C., \& CREWs, D. (in press). Effects of intracranial implantation of dihydrotestosterone on sexual behavior in male Cnemidophorus inomatus, a direct sexual ancestor of a parthenogenetic lizard. Hormones \& Behavior.

SACHS, B. D., \& MEISEL, R. L. (1988). The physiology of male sexual behavior. In E. Knobil \& J. D. Neill (Eds.), The physiology of reproduction (Vol. 2, pp. 1393-1486). New York: Raven Press.

SCOTT, W. J., \& Holsen, J. F. (1977). Weight differences in rat embryos prior to sexual differentiation. Journal of Embryology \& Experimental Morphology, 40, 259-263.

Sellar, M. J. , \& Perkins-Cole, K. J. (1987). Sex differences in mouse embryonic development at neurulation. Journal of Reproduction \& Fertility, 79, 159-161

STACEY, N. (1987). Role of hormones and pheromones in fish reproductive behavior. In D. Crews (Ed.), Psychobiology of reproductive behavior (pp. 28-60). Englewood Cliffs, NJ: Prentice-Hall.

Swain, J. L., Stewart, T. A., \& Leder, P. (1987). Parental legacy determines methylation and expression of an autosomal transgene: A molecular mechanism for parental imprinting. Cell, 50, 719-727.

TsunOda, Y., ToKunaga, T., \& SugIE, T. (1985). Altered sex ratio of live young after transfer of fast- and slow-developing mouse embryos. Gamete Research, 12, 301-304.

W ADE, J., \& CREWS, D. (1988). [The hormonal control of female-like receptivity in the parthenogenetic lizard: Intracranial implantation studies.] Unpublished raw data.

WAGNER. (1980). Appendix in Bull, 1980.

Wai-Sum, O., Short, R. V., Renfree, M. B., \& ShaW, G. (1988). Primary genetic control of somatic sexual differentiation in a mammal. Nature, 331, 716-717.

WERNER, Y. L. (1980). Apparent homosexual behavior in an all-female population of a lizard, Lepidodactylus lugubris, and its probable interpretation. Zeitschrift für Tierpsychologie, 54, 144-150.

Wilson, J. D., George, F. W., \& Griffen, J. E. (1981). The hormonal control of sexual development. Science, 211, 1278-1284.

YAHR, P. (1988). Sexual differentiation of behavior in the context of developmental neurobiology. In E. M. Blass (Ed.), Handbook of behavioral neurobiology (Vol. 9, pp. 197-243). New York: Plenum.

ZAwORSKı, J. P. (1987). Observations on unusual behavior in the parthenogenetic gecko, Lepidodactylus lugubris Fitzinger. Bulletin of the Chicago Herpetological Society, 22, 76.

(Manuscript received April 15, 1988.) 